\title{
Understanding the Prevalence and Forms of Cyber Bullying at Univen: A Pilot Study
}

\author{
Memory Mabika, University of Venda, South Africa \\ BevelynDube, University of Venda, South Africa
}

\begin{abstract}
Bullying is a phenomenon which is as old as the human race. However, with the advent of new Information Communication Technologies (ICTs) new forms of bullying, commonly known as cyber bullying, have developed in society. The phenomenon is perceived by many to be a deviant practice among adolescents and teenagers in environments such as schools and colleges. Much academic work on cyber bullying has focused on school children, yet in institutions of higher learning such as universities show that cyber bullying has also become a noticeable problem, worthy of study. Using the Routine Activity Theory (RAT), this article explores the prevalence and forms of cyber bullying at the University of Venda (UNIVEN), a historically disadvantaged, rural-based institution of higher learning, which is still facing various capacity and infrastructural challenges. Key data that form the basis of this article were collected through a structured questionnaire from a sample of 2014 first year students at UNIVEN. The findings revealed high levels of cyber bullying among UNIVEN first year students. The study findings also revealed a need for more research on the phenomenon in order to establish the causes, effects and possible solutions to this growing scourge at UNIVEN.
\end{abstract}

Keywords: Cyber bullying, ICTs, prevalence, Routine Activity Theory, students, University of Venda 


\section{Introduction}

Bullying among students is not really a new phenomenon. However, the advent of new Information Communication Technologies (ICTs) has moved bullying from the school grounds to the realm of the electronic world (Icellioglu \& Ozden, 2014:42). ICTs have aggravated the problem and brought with them new forms of bullying, commonly known as cyber bullying. New media technologies have expanded the public sphere to levels which earlier generations never really envisaged. This increased interaction particularly on the cyberspace has given birth to new forms of bullying known as cyber bullying. Cyber bullying can be defined as the use of ICTs to carry out a series of acts intended to harm another who cannot defend him or herself (Piotrowski, 2012). At the click of a button, one can destroy, injure, humiliate or worse still drive another person to his/her grave.

Perpetrators of cyber bullying manipulate the ever advancing new communication technologies such as cell phones, emails and the numerous Internet-based social networks to harass their victims. These new ICTs have increased the speed with which information is shared among users on the cyber space, and consequently exacerbating cyber violence. Cyber bullying is driven by perceived anonymity, unrestrained information publishing and easy access to e-communication which has removed the need for physical contact of the perpetrator and victim (Carter, 2013).

According to Badenhorst (2011:1), "advances in technology, the communication and the general changes in communication patterns have resulted in unacceptable and undesirable communication behaviour (or misbehaviour) among children through the use of these technologies." Cyber bullying has a negative impact on the well-being of the students that is on perpetrators and victims, the institutions of learning and the nation as a whole. This phenomenon should be addressed and given as much attention as traditional bullying (see Burton \&Mutongwizo, 2009; Bailey, 2012; Icellioglu\&Ozden, 2013). In South Africa, many students, as they get acquainted with various mobile phone and Internet-based services are vulnerable to cyber bullying, as either perpetrators or victims,

Although cyber bullying is growing rapidly, globally, and has attracted considerable attention from researchers worldwide, this scourge has not yet received adequate attention in South Africa. According to Alfreds (2013), in South Africa, the extent of cyber bullying is 
underestimated even though it is clear that the problem is growing. Available literature reveals that there is no study that has been carried out or published so far on cyber bullying at the University of Venda (UNIVEN). This article, therefore, presents the findings of a study carried out among the 2014 University of Venda students to establish whether the students are aware of the different forms of cyber bullying, as well as to examine the prevalence of this problem among the students. The study also sought to establish the forms of cyber bullying that are prevalent among the students.

\section{What is Cyber Bullying?}

Cyber bullying is a new online phenomenon which is growing as fast as the ICTs themselves. While ICTs have many benefits for users, cyber bullying is, unfortunately, a negative offshoot of the ICTs which has become a new weapon of destruction (Zacchilli\& Valerio, 2011). Cyber bullying, is also variously known as cyber violence, Internet harassment, cyber aggression, Internet bullying and online harassment (Popovac\&Leoschut, 2012). Although studies have generally been done on cyber bullying globally, and Africa in particular, researchers have failed to keep up with the proliferation of ICTs and all its challenges (Obijiofor, Inayatullah\& Stevenson, 2000). This means that there is a dearth of literature and this has, in turn, created a vacuum on issues surrounding cyber bullying. Scholars are still trying to understand this new form of bullying, hence there is still no agreement on what cyber bullying entails (Burton \&Mutongwizo, 2009; Zacchilli\& Valerio, 2011; Cesaroni, Downing, \&Alvi, 2012; Naruskov, Luik, Nocentinti\&Menesini, 2012).

ICTs are a central element in cyber bullying. According to Langos (2012:285), cyber bullying involves the use of ICTs to carry out a series of acts intended to harm another who cannot defend him or herself. Burton and Mutongwizo (2009:2) also defines cyber bullying as aggressive, intentional acts repeatedly carried out over time against victims who cannot easily defend themselves by groups or individuals using electronic forms of contact. Scholars seem to be agreed that victims of cyber-bullying are unable to defend themselves and that they are at the mercy of their tormentors. Cyber bullying is not only perpetrated by individuals but it can also be initiated by groups, and victims of this scourge can also be individuals or groups (Smith et al., 2008). 
Cyber bullying differs from traditional bullying in that on the cyberspace users can choose to remain anonymous or they can expose themselves depending on their purpose of engaging in the act. In their study, Icellioglu and Ozden (2014) established that cyber bullying has become a preferred style, especially amongst the youth, to express their anger in anonymity. The fact that the perpetrators can carry out the act of bullying without revealing their real identity, has resulted in the proliferation of various types of cyber bullying behaviours among youths.

\section{Literature Review}

As revealed by the various definitions of cyber bullying above, cyber bullying is a phenomenon which involves the use of ICTs to harass or attack vulnerable victims. Cyber bullying manifests itself in various ways, for example, aggressive instant messages (sms, mms, chat messages, social network inscriptions, and threatening emails), threatening calls, nude private videos or altered images and videos published on public platforms to humiliate or embarrass the victims (Popovic-Citic, Djuric\&Cvetkovic, 2011; Naruskovet al., 2012; Popovac\&Leoschut, 2012).

According to Popovac and Leoschut (2012), while adults use terms such as 'cyber bullying' to refer to this ICT-related form of bullying, young people refer to it as 'drama', revealing how they trivialise the damaging effects of cyber bulling on their peers. This underlines the need for studies which focus on youth and their attitude towards cyber bullying. Popovac and Leoschut (2012:2) argue that there is need to educate youth about cyber bullying since young people may not necessarily place themselves within a bullying rhetoric. A child-centred response to youth cyber violence is critical since the effects of cyber violence on young people might be more detrimental than they are on adults (Burton \&Mutongwizo, 2009; Rafferty, 2011; Cesaroni, Downing, \&Alvi, 2012; Popovac \& Leoschut, 2012; Kowalski \& Limber, 2013; Shumba \& Ncontsa, 2013; Wong, Chan \& Cheng, 2013; Incelliogle \& Ozden, 2014; Ozden \& Icellioglu, 2014). For instance, Cesaroni, Downing, and Alvi (2012) argue that cyber bullying has the potential for real harm since it is a psychologically devastating form of social cruelty.

Kowalski and Limber (2013) assert that, besides causing psychological and physical ailments among the victims, cyber bullying it can cause serious academic problems on students. 
Shumba and Ncontsa (2013), in their study, also concluded that cyber violence in schools can result in loss of concentration, poor academic performance, missing classes and depression. Alluding to its seriousness, Popovic-Citic, Djuric and Cvetkovic (2011:413) add that young people use new technologies to transcend the boundaries of real life and to effectively harm others. Thus, cyber bullying can be viewed as an extension of traditional bullying. They further argue that cyber bullying has hardened students to levels where ordinary norms are easily forgotten, making young people uncharacteristically cruel and uncontrollable (Ibid).

Although limited, studies on students' cyber bullying habits highlight the seriousness of the problem and indicate that the challenge warrants attention not only globally, but is South Africa as well (Burton \& Mutongwizo, 2009; Badenhorst, 2011; Popovic-Citic, Djuric \& Cvetkovic, 2011). It is thus the intention of this study to investigate the prevalence, as well as the types of cyber bullying among first year students at UNIVEN. This is a group which consists of some young people who are, for the first time in their lives, operating on cyber space without the protection of their parents and guardians. Even though many have access to mobile phones from a tender age, most join the cyberspace oblivious of the dangers lurking in it and which they have little control over. Establishing the prevalence and the various ways in which these not so techno-savvy youths indulge in hurtful acts on the cyberspace is an interesting starting point in a series of studies which will add to the available body of knowledge on cyber bullying among students in South African universities.

\section{Theoretical Framework}

This study views cyber bullying as not just another deviant behaviour, but as a social problem, which can have negative effects on students' learning not only in South Africa, but globally as well. Cyber bullying is a criminal offence that scholars still seek to understand. The study adopted Cohen and Felson's (1979) Routine Activity Theory (RAT) to examine the prevalence of cyber bullying as well as the ways in which it manifests itself among UNIVEN students. Cohen and Felson developed this theory after carrying out a study, for more than twenty years, which examined temporal changes in U.S. crime rates (Wilcox, 2010: 979). RAT is used to explain victimisation (Ibid).

Since the 20th century, there has been a shift among scholars from viewing "crime" as the behaviour of an offender but as a "system," which involves the offender, the victim, and the 
context that facilitates victimisation of the target by the offender (Wilcox, 2010: 978). According to Veenstra (2009:3), there is a convergence of three elements for crimes, such as cyber bullying, to occur. There should be offenders, suitable targets and an absence of capable guardians for deviance to occur. It is argued that these three elements constitute a tripod holding a platform on which crimes occur (Dolu, 2009:4), and that, if one of the legs is broken, the stand will fall down and crime will not happen (Delice, 2011). Proponents of RAT, thus, see cyber bullying as a combination of various components, which contribute to the success of the various cyber violence acts.

Veenstra's (2009)' findings reveal that bullies are motivated by three different reasons as follows: (1) because bullies are bullied themselves, most cyber bullying is a reaction to previous bullying encounters; (2) because bullies want to take revenge for something the victim did to them; and (3) some just do it for fun. However, Finkelhor and Asdigian (1996) reject the assumption by RAT that violence befalls only those who have perpetrated such acts before or those who lack parental guardiance or are detached from their primary caregivers or those who are socially and physically weaker. They argue that the theory's assumptions of the victim's contributions to the act are not broad enough. However, despite the limitations of this theory, it was found to be suitable for this particular study.

\section{Methodology}

This exploratory study was carried out to establish the prevalence and forms of cyber bullying among first year students at the University of Venda (UNIVEN). UNIVEN is a historically disadvantaged institution, which is still facing various capacity and infrastructural challenges (Nendila, April, 2014). It is located in the semi-rural small town of Thohoyandou. The institution has eight different schools which, between them, enrolled a total of 3534 first year students in 2014. The researchers obtained the statistics of the first time entering students enrolled in 2014 from the institution's Higher Education Information Management System (Hemis) office which deals with university statistics. Thus those who were repeating modules or had changed to a different degree but were at the institution the previous year were not included.

The population selected for this study consisted of all first entering students from all the eight schools. Numbers of students enrolled in each school were as follows: Agriculture (156), 
Education (662), Environmental Sciences (357), Health Sciences (310), Human \& Social Sciences (750), Law (273) Management Sciences (541), and Mathematics \& Natural Sciences (485). Although there are other strata such as departments within the schools, gender and age, the study selected participants solely on the schools they are enrolled in and on their gender. Both males and females were selected on a fifty-fifty basis.

In view of the varied numbers in each school, the proportionate stratified sampling strategy was employed to select respondents from each school. Ten per cent $(10 \%)$ of the students were selected from each school to participate in this exploratory study. According to Johansonand Brooks (2010), when exploratory or pilot studies are under consideration, a 10\% sample is a reasonable number. As a result a total of 354 students (177 males and 177 females) was selected to participate in this study. Table I shows the number of participants per school.

Table 1: Number of participants per school

\begin{tabular}{|l|l|}
\hline School & Number of participants \\
\hline Agriculture & 16 \\
\hline Education & 66 \\
\hline Environmental Sciences & 36 \\
\hline Health & 31 \\
\hline Human and Social Sciences & 75 \\
\hline Law & 27 \\
\hline Management Sciences & 54 \\
\hline Mathematics and Natural Sciences & 49 \\
\hline
\end{tabular}

According to Du Plooy (2001:108), the proportionate stratified sampling procedure is used where the sizes of the strata sampled are based on their proportions in the population. The strength of using this sampling strategy is that various characteristics can be represented in the sample in the proportion they occur in the population, ensuring the representativeness of relevant variables (Du Plooy, 2001:109).

After determining the numbers of students to be selected from each school, the study went on to employ the convenience sampling strategy to select the actual participants. Convenient 
sampling allows the researchers to select subjects according to their availability or because of the ease with which they can be accessed (Babbie, 2005). The disadvantage with this sampling technique is that the sample might not be representative of the population and the findings might be biased. The actual students who responded to this survey questionnaire voluntarily participated in this study after the researcher had first explained the purpose of the study and described what cyber bullying entailed. Most of the students were eager to participate in the study therefore data collection was very easy and all the questionnaires were returned.

The study employed a quantitative questionnaire survey to collect data from the selected group of students. The quantitative design was chosen because it helped the researcher to predict, describe and explain quantities, degrees and relationships. Thus the findings allowed this study to establish prevalence and forms of cyber bullying among first year UNIVEN students.

Permission to carry out this study was sought and granted by the University of Venda Health, Safety, and Research Ethics Committee (HSREC).

\section{Results and Discussion}

Based on a survey of 354 students, the study investigated the prevalence and forms of cyber bullying among UNIVEN first entering students. The study utilised RAT which proposes that, for cyber bullying to occur, three elements have to converge, namely offenders, suitable targets and an absence of capable guardians. These elements constitute a tripod holding a platform on which crimes occur (Dolu, 2009; Delice, 2011). RAT further argues that if one of the tripod legs breaks or does not exist, crime will not take place.

The study confirmed that the majority of the participants (79\%) lived in the surrounding rural communities and peri-urban areas near the institution. Only $21 \%$ resided in an urban area.

Ninety-three per cent (93\%) of the students identified their economic status as average to poor. This has a significant impact on the usage of ICTs as shown by the fact that all the students who described their economic status as above average to affluent had daily access to the Internet, while $19 \%$ of those who described their economic position as poor had no access 
to the Internet. However, $57 \%$ of the poor accessed the Internet regularly. The study revealed that affluent respondents were more prone to use the Internet to bully others or to be bullied themselves. Thus, access to the Internet and being exposed to Internet harassment or using it to harass other users appears to be closely linked. This finding is similar to Popovac and Leoschut's (2012) which revealed that young people who access the Internet daily are exposed to high levels of online aggression.

Ninety eight per cent (98\%) of the students have access to cell phones, while $86 \%$ of the students have access to the Internet though at varying degrees. Although many also access Internet through their mobile phones, the study established that not all these phones have Internet access. Some are just simply ordinary phones which are used to call and send text messages. Even though $86 \%$ were able to access the Internet through laptops and desktops, this number is still fairly low compared to other more developed institutions and countries where these gargets are easily accessed (Beranet al., 2012).

Findings also revealed that the extent to which students are aware of cyber bullying varies from school to school. In the school of Agriculture, only 25\% of the respondents knew about cyber bullying; in Education 53\%; Environmental Sciences 53\%; Health 42\%; Law 26\%; Management Sciences 40\%; Mathematics and Natural Sciences 33\% and Human and Social Sciences had the highest at $60 \%$. These results shows that, on average, the majority of students in five schools (Agriculture 75\%, Health 58\%, Law 74\%, Management Sciences $60 \%$, Mathematics and Natural Sciences 67\%) were not aware of cyber bullying even though some of these students were involved in the cyber bullying as victims or perpetrators or both. Though observation was not really an instrument adopted for this study, one could not avoid observing what was happening whist collecting data. Some of the students were actually surprised when the researchers defined cyber bullying and pointed that it was a crime in South Africa. They revealed that they thought it was one of those things which no one really cared about. This confirms Popovac and Leoschut's (2012) assertion that young people are not aware of what cyber bullying involves.

More than half of the study participants revealed that they have been involved in the act of cyber bullying as perpetrators, victims or both. The study established that marital status, age and gender had negligible effects on cyber bullying activities among UNIVEN students. Only 
25 respondents out of a total of 354 participants ( 8 male and 17 female) were married. Thus less than $5 \%$ of the male respondents and less than $10 \%$ of the female respondents were married. Out of 25 married respondents over half participated in cyber bullying as victims, perpetrators and both. Both male and female participants of all ages and marital status revealed almost similar characteristics in relation to their roles as perpetrators and victims of cyber bullying. This is in contrast with Popovic-Citic et al. (2011) and Kowalski andLimber's (2013) findings which show that gender differences play a significant role in students' bullying behaviours. Kowalski and Limber (2013) argue that females were prone to engage in cyber bullying more than their male counterparts, while Popovic-Citic et al. (2011) are of the view that males were more likely to be involved in cyber bullying than their female counterparts.

The findings revealed that 207 (58.5\%) of the participants had encountered cyber bullying while $147(41.5 \%)$ had not.Data reveals that $130(62.8 \%)$ encountered cyber bullying as victims only, 17 (8.2\%) were bullies only while 60 (29\%) were both victims and bullies. Data also revealed that most of the students encounter cyber bullying through cell phones as compared to the Internet and emails. This is not surprising because the majority of these students own a cellphone handset. This seems to resonate with Popovic-Citicet al. (2011) and Wong et al. 's (2013) findings that when students have access to technologies they are bound to use them negatively. Although more than half of the study participants revealed that they have been involved in cyber bullying as either perpetrators, victims or both, most of them were not aware of the term 'cyber bullying'. It was also confirmed in this study that the students who were cyber bullied through the Internet and emails also had regular access to the Internet. Thus there is a correlation between exposure to and abuse of these gadgets. According to Popovic-Citic et al. (2011:419), "information and communication technologies have become a part of the everyday lives of Serbian adolescents, and therefore it can be expected that cyber bullying problems may occur."

The study also confirmed that even though most of the students enrolled at UNIVEN come from poor to average rural backgrounds, they had access to ICTs, particularly cell phones and this creates fertile grounds for misuse of these gadgets to harass or abuse others. The portability of cell phones makes it easy for individuals to send harassing messages to others. They can also be used to take pictures and connect Internet (Beranet al., 2012). Some 
students identified being tagged to embarrassing or indecent pictures/videos accessed by many without their consent and being lured to engage in e-sex via their mobile phones or Skype as some of the methods in which they have encountered cyber bullying.

Using RAT to analyse the findings, one would agree that all three of the elements that lead to cyber bullying, namely offenders, suitable targets and lack of suitable guardians are present among UNIVEN students and that they are made possible by an increased access and usage of cell phones among students. According to Dolu (2009) and Delice, (2011) the third leg, develops due to the absence of capable guardians to control and monitor deviant behaviours. Even though most of these students reside in communities that surround the university, they spend a greater part of their day at the university where their parents and guardians have no control on them. Besides, mobile phones are personal self-centred gadgets which many use independently (Van den Berg, 2012). It would not be possible for lecturers to act in loco parentis as their main mandate is to teach students and not to monitor how they use their cell phones. It has to be remembered that students at universities are considered to be young adults who do not require monitoring by lecturers. Thus, the unchecked use of mobile phones by students at UNIVEN is likely to result in negative usage and abuse of these technologies (see Popovic-Citic et at., 2011).

Though most studies argue that anonymity of the perpetrator, which is made possible by the new technologies, encourages cyber bullying, data revealed that most victims of cyber bullying $(37 \%)$ in the study knew who their perpetrators were than those who did not know their abusers $(16.9 \%)$. This could be linked to the fact that most of these students were not aware of the gravity of their acts hence they did not make any effort to cover up their tracks. The other reason why some of these perpetrators did not hide their identities could be linked to the methods or nature of bullying most of these students used. Most of these perpetrators used the mobile phones to inflict pain, humiliate, harass or threaten their victims, so victims could easily identify their abusers through their caller IDs.

Of the 132 students who knew their abusers, 59 said the perpetrators were from UNIVEN while 73 were not from UNIVEN. However the majority were students even though they were not from UNIVEN. Ninety-seven (97) were students while 35 were adults. 


\section{Conclusions}

The study revealed that cyber bullying is very rife at UNIVEN amongst first year students even though most of the respondents professed ignorance of the practice and what it entailed. A sizable number of students haveaccess to the Internet, though not on an equal basis. This study revealed that this limits its usage for cyber bullying among students. However, almost all the students have access to mobile phones which makes them the highest used technology for cyber bullying amongst UNIVEN students. However, most of these phones are simple handsets which have no Internet provision, meaning that most cyber bullying at UNIVEN is done via sms. 


\section{References}

Alfreds, D. (2013, August 12). Cyber bullying growing in SA. Retrieved May 24, 2015, from News24: http://m.news24.com/news24/Technology/News/Cyber-bullying-growingin-SA-20130812

Babbie, L. (2005). The Practice of Social Research. Cape Town: Van Schaik Booksellers.

Badenhorst, C. (2011, August). Legal Responses to Cyber Bullying and Sexting in South Africa. Centre for Justice and Crime Prevention(CJCP Issue Paper No.10). Claremont, Gauteng, South Africa: Centre for Justice and Crime Prevention.

Bailey, C. (2012, February 10). Bullting on the Increase. Retrieved 04 17, 2014, from IOL: http://www.iol.co.za/news/south-africa/gauteng/bullying-on-the-increase-1.1231474?

Beran, T. N., Ridaldi, C., Bickham, D. S., \& Rich, M. (2012). Evidence for the Need to Support Adolescents Dealing with Harassment and Vyber-Harassment: Prevalence, Progression, and Impact. School Psychology International, 33(5), 562-576.

Burton, P., \& Mutongwizo, T. (2009, December). Inescapable Violence: Cyber Bullying and Electronic Violence Against Young People in South Africa. Centre for Justice and Crime Prevention. Claremont, Gauteng, South Africa: Centre for Justice and Crime Prevention.

Carter, M. A. (2013). Protecting Oneself from Cyber Bullying on Social Media Sites - A Study of Undergraduate Students. Procedia - Social and Behavioral Sciences, 93, 1229-1235.

Cesaroni, C., Downing, S., \& Alvi, S. (2012). Bullying Enters the 21st Century? Turning a Critical Eye ot Cyber-bullying Research. Youth Justice, 12(3), 119-211.

Delice, M. (2011). How the Routine Activity Theory can Help. Turkish Journal of Police Studies, 13(1), 137-154.

Dolu, Osman, (2009), In Delice, M, (2011), How the Routine Activity Theory can Help. Turkish Journal of Police Studies, 13(1), 137-154.

Finkelhor, D., \& Asdigian, N. L. (1996). Factors for Youth Victimization: Beyond a Lifestyles/Routine Activities Theory Approach. Violence and Victims, 11(1), 3-19.

Icellioglu, S., \& Ozden, M. S. (2014). Cyberbullying: A New Kind of Peer Bullying Through Online Technology and its Relationship with Aggression and Social Anxiety. Procedia - Social Behavioral Sciences, 116, 4241-4245.

Kowalski, R. M., \& Limber, S. P. (2013). Psychological, Physical, and Academic Correlates of Cyberbullying and Traditional Bullying. Journal of Adolescent Health, S13-S20. 
Langos, C. (2012). Cyberbullying: The Challenge to Define. Cybepyschology, Behaviour, and Social Networking, 15(6), 285-289.

Naruskov, K., Luik, P., Nocentini, A., \& Menesini, E. (2012). Estonian Students' Perception and Definition of Vyberbullying. Trames, 16(4), 323-343.

Ncontsa, V. N., \& Shumba, A. (2013). The Nature, Causes and Effects of School Violence in South African High Schools. Journal of Education, 33(3), 1-15.

Obijiofor, L. M., Inayatullah, S., \& Stevenson, T. (2000). Impact of new information and communication technologies (ICTs) on socio-economic and educational development of Africa and the Asia-Pacific. Journal of Futures Studies, 4(2), 21-66.

Ozden, M. S., \& Icellioglu, S. (2014). The Perceptions of Cyberbullying and Cybervictimization by university students Students in Terms of their Personality Factors. 5th World Conference on Educational Sciences - WCES 2013 (pp. 43794383). Prodcedia - Social Behavioral Sciences.

Popocic-Citic, B., Djuric, S., \& Cvetkovic, V. (2011). The Prevalence of Cyberbullying among Adolecents: A Case of Middle Schools in Serbia. School Psychology International, 32(4), 412-424.

Popovac, M., \& Leoschut, L. (2012, June). Cyber bullying in South Africa: Impact and Responses. Centre for Justice and Crime Prevention. Claremont, Gauteng, South Africa: Centre for Justice and Crime Prevention.

Bernal, C., \& Angulo, F. (2013). Interactions of Young Andalusian People. Revista Científica de Educomunicación, 25-30.

Beran, T. N., Ridaldi, C., Bickham, D. S., \& Rich, M. (2012). Evidence for the Need to Support Adolescents Dealing with Harassment and Vyber-Harassment: Prevalence, Progression, and Impact. School Psychology International, 33(5), 562-576.

Beran, T., \& Li, Q. (2005). Cyber-harassment: A study of a new method for an old Behaviour. Journal of Educational Computing Research, 32(3), 265-277.

Cowie, H. A. (2011). Coping with the emotional impact of bullying and cyberbullying: How researchcan inform practice. International Journal of Emotional Education,3(2), 5056.

Delice, M. (2011). How the Routine Activity Theory can Help. Turkish Journal of Police Studies, 13(1), 137-154. 
Dolu, Osman, (2009), In Delice, M, (2011), How the Routine Activity Theory can Help. Turkish Journal of Police Studies, 13(1), 137-154.

Dornyei, Z. (2007). Research Methods in Applied Linguistics: Quantitative, Qualitative and Mixed Methodologies. Oxford: Oxford University Press.

Dueck, S. (n.d.). Cyberbullying: A new place for an old practice.

Gibbs, A. (1997). Focus groups. Social research update, 19(8), 1-8.

Gillespie, A. A. (2006, June). Cyber-bullying and Harassment of Teenagers: The Legal Response. Journal of Social Welfare \& Family Law, 28(2), 123-136.

Hanewald, R. (2008). Confronting the pedagogical challenge of cyber safety. Australian Journal for Teacher Education, 33(3), 1-16.

Jaishankar, K., \& Uma Sankary, V. (2005). Cyber stalking: A global menace in the information super highway. ERCES Online Quarterly Review, 2(3).

Jordan, J., Lynch, U., Moutray, M., O’Hagan, M. T., Orr, J., Peake, S., \& Power, J. (2007). Using focus groups to research sensitive issues: Insights from group interviews on nursing in the Northern Ireland "Troubles". International Journal of Qualitative Methods, 6(4), 1-19

Juvonen, J., \& Gross, E. F. (2008). Extending the school grounds?-Bullying experiences in cyberspace Journal of School health. Journal of School health, 78(9), 496-505.

Krueger, R. A., \& Casey, M. A. (2002). Designing and conducting focus group interviews. Social Analysis, Selected Tools and Techniques", Krueger, RA, MA Casey, J. Donner, S. Kirsch and JN Maack, 4-23.

Langos, C. (2012). Cyberbullying: The Challenge to Define. Cybepyschology, Behaviour, and Social Networking, 15(6), 285-289.

Mabika, M. (2015). Understanding Cyber bullying at UNIVEN: A pilot study. Unpublished conference paper.

Miller, C. (2007, January 05). Zimbabwean Broadcasting: From Colin Miller: Zimbabwe. Retrieved January 23, 2013, from Zimbaber Broadcast History: http://www.oldradio.com/archives/international/zimb.htm

Notar, C. E., Padgett, S., \& Roden, J. (2013). Cyberbullying: A Review of the Literature. Universal Journal of Educational Research, 1(1), 1-9.

O'Keeffe, G. S., \& Clarke-Pearson, K. (2011). The impact of social media on children, adolescents, and families. Pediatrics, 127(4), 800-804. 
Onwuegbuzie, A. J., \& Leech, N. L. (2007). Sampling Designs in Qualitative Research: Making the Sampling Process More Public. The Qualitative Report, 12(2), 238-254.

Patchin, J. W., \& Hinduja, S. (2006). Bullies move beyond the schoolyard a preliminary look at cyberbullying. Youth violence and juvenile justice, 4(2), 148-169.

Patton, M. Q. (1990). Qualitative Research and Evaluation Methods (2nd ed.). Newbury Park, CA: Sage.

Preacher, K. J., \& Hayes, A. F. (2004). SPSS and SAS procedures for estimating indirect effects in simple mediation models. Behaviour research methods, instruments, \& computers, 36(4), 717-731.

Piotrowski, C. (2012). From Workplace Bullying to Cyberbullying: The Enigma of EHarassment in Modern Organizations. Organization Development Journal, 30(4), 4453.

Poland, S. (2010). Cyberbullying continues to challenge educators. In Notar, C. E., Padgett, S., \& Roden, J. (2013). Cyberbullying: A Review of the Literature. Universal Journal of Educational Research, 1(1), 1-9.

Popovac, M., \& Leoschut, L. (2012, June). Cyber bullying in South Africa: Impact and Responses. Centre for Justice and Crime Prevention. Claremont, Gauteng, South Africa: Centre for Justice and Crime Prevention.

Šléglová, V., \& Černá, A. (2011). Cyberbullying in Adolescent Victims: Perception and Coping. Journal of Psychosocial Research on Cyberspace, 5(2), 1-15.

Smith, P. K., Mahdavi, J., Carvalho, M., Fisher, S., Russell, S., \& Tippett, N. (2008). Cyberbullying: Its nature and impact in secondary school pupils. Journal of child psychology and psychiatry, 49(4), 376-385.

Univen Visits University of Fort Hare. (2014, April). Nendila: Newsletter of the University of Venda, p. 1.

Van den Berg, P. E., Arentze, T. A., \& Timmermans, H. P. (2012). New ICTs and Social Interaction: Modelling Communication Frequency and Communication Mode Choice. New Media Society, 14(6), 987-1003.

Veenstra, S. (2009). Cyberbullying:An Explanatory Analysis. University of Leicester, MSc Community Safety, Department of Criminology .

Wilcox, P. (2010). Victimization, Theories of. In B. Fisher, \& S. Lab (Eds.), Enclopedia of Victimology and Crime Prevention (pp. 978-986). Thousand Oaks: SAGE Publications. 
Wong, D. W., Chan, H. O., \& Cheng, C. K. (2013). Cyberbullying Perpertration and Victimization among adolescents in Hong Kong. Children and Youth Services Review, 133-140.

Zacchilli, T. L., \& Valerio, C. Y. (2011). The Knowledge and Prevalence of Cyberullying in a College Sample. Journal od Scientific Psychology, 11-23. 